\title{
Mektepten Şekâvete: Hormekli Zeynel Efendi’nin Hikâyesinin Aşireti ve Bölge Tarihindeki Yeri*
}

\section{From Mektep (School) to Banditry: The Place of Hormekli Zeynel within His Tribe and the History of the Region}

\author{
Yalçın Çakmak $^{\text {a,** }}$ \\ ${ }^{a}$ Dr. Öğr. Üyesi, Munzur Üniversitesi, Edebiyat Fakültesi, Tarih Bölümü, 62000, Tunceli/Türkiye \\ ORCID: 0000-0002-7065-2659
}

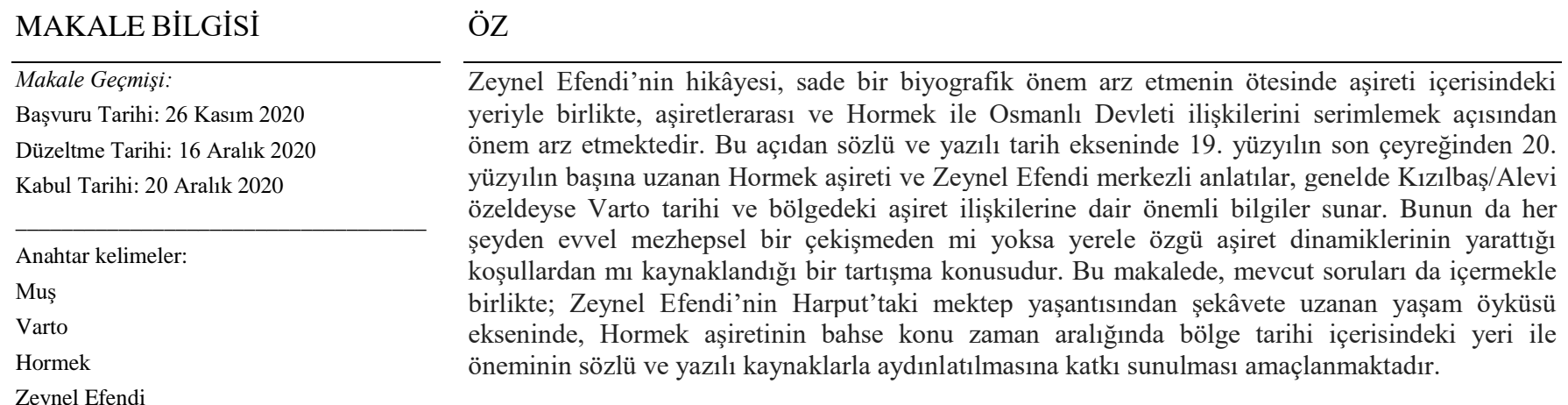

Zeynel Efendi

Kızılbaş/Alevi

\section{A R T I C L E I N F O}

\section{Article history:}

Received 26 November 2020

Received in revised form 16 December 2020

Accepted 20 December 2020

\section{Keywords:}

Muş

Varto

Hormek

Zeynel Efendi

Kizilbash/Alevi

\section{A B S T R A C T}

The history of Zeynel Efendi, not only as a biography but also in terms of his position in his tribe is important to lay bare his intertribal relations and his relationship with the Ottoman rule. In this regard narratives centered on Zeynel Efendi give us remarkable information about the relations of the tribes and the history of Varto particularly, and in a broader sense, Kızılbaş/Alevi history from the last quarter of the 19th century to the early 20th century in the context of both written and oral history. It's a matter of debate today if it originated primarily from a sectarian conflict or from the conditions that had been created by the tribal dynamics. This article aims to reveal the importance the history of the tribe Holmek and its place in the history of the region, taking into consideration of the history of his life from the school to the banditry age through written and oral historical sources.

\section{Giriş}

Vartolu Zeynel ya da Zeynel Efendi, bugün bilhassa Varto Kızılbaşları ve özellikle de mensubu bulunduğu Hormek aşireti içerisinde adı sıklıkla anılan tarihsel bir figürdür. Bunda Zeynel'in, adı etrafinda inşa edilen anlatılar merkezli, aşiretin kendi tarihi ve kimliğinin tahkiminde bilhassa ihtiyaç duyduğu kahramanlık söylemlerinin küçümsenmeyecek oranda yeri vardır. Çünkü -aşağıda da görüleceği gibi- hem sözlü hem de yazıll anlatılarda, Zeynel Efendi'nin gerek Cibran aşireti ile gerekse eşkıya olarak nitelendirildikten sonra Osmanlı güçleriyle giriştiği

\footnotetext{
* Bu çalışma, 22-23 Ekim 2020 tarihlerinde Muş Alparslan Üniversitesinde düzenlenen II. Uluslararası Muş Sempozyumunda sözlü bildiri olarak sunulmuştur.

** Sorumlu yazar/Corresponding author.

e-posta: yalcincakmak82@gmail.com
} 
mücadelenin seyrinden ötürü Kızılbaş Hormek aşiretinin sembol yüklü tarihi bir karakteri haline geldiği görülür.

Zeynel Efendi eksenli dile getirilen ifadelerin, sadece kendi şahsından ziyade Hormek aşiretinin bölgedeki diğer aşiret ve devlet ile ilişkisine dair de önemli bir bakış açısı sunduğu söylenebilir. Bu bakımdan Zeynel üzerinden ifade bulan anlatıların bir yanıyla Hormek ve Cibran aşiretleri arasındaki ilişkiye 1 şı tuttuğunu ifade etmek abartılı olmasa gerektir. Zira Hormek ile ilgili bir anlatıda yanı başındaki rakip aşiretlerden biri olan Cibran'ın görmezden gelinmesi eksik bir anlatı olacaktır. Bu yönüyle, Fırat'ın da ifade ettiği gibi "Varto ve Bingöl'deki Hormek tarihinin Cibran olmadan yazılamayacağını" dile getirmek (Kamil Fırat ile kişisel görüşme) bilhassa bölgedeki komşu aşiretlerin dini, siyasi, ekonomik ve toplumsal yaşayışları bakımından -olumlu ya da olumsuz olduğuna bakılmaksızın- seyreden zaruri bir ilişkinin gerçekçiliğine temas eder.

17. yüzyılın ortasına kadar Varto ve civarında varlıklarına rastlanılmayan her iki aşiretin (Alanoğlu, 2020) bu tarihten sonra bölgede varlık göstermeleri, ortak bir temas alanı üzerinde buluştuklarının işaretidir. $\mathrm{Bu}$ temasın da yer yer barış yer yer de çatışmalarla sürdüğü anlaşılmıştır. Bu açıdan Hormekliler ile ilgili yaygın kanaat 18. yüzyılın ortalarında bir "namus meselesi"nden ötürü Dersim'den buraya geldikleriyken (Kıran, 2019: 73-74, 77-80, 188-190) bir diğeri de 1635 'ten itibaren yavaş yavaş bölgeye yerleşmeye başladıkları yönündedir. Böylece Varto bölgesine ilk gelen Kızılbaş aşiretleri arasında sırasıyla Avdelan (Abdalan), Lolan ve Hormek $^{1}$ gelmekte olup (Fırat, 1961: 56-65) Hormekliler içinde de ilk sırayı Sor Memed ve Kara Davut sonrasında da Pircanlar almıştır. Bir diğer Hormek kolu olarak aşiretin son yönetici kolu olan Feranların gelişi ise 19. yüzyılın ilk çeyreği olup, esas vatanları Dersim'dir. Feranlıların gelişiyle diğer Hormekliler içinde ağırlıklarını hissettirmiş ve Cumhuriyet ile birlikte devlet nezdinde Hormek'in dikkate alınan kolu haline gelmişlerdir (Kamil Fırat ile kişisel görüşme).

Cibranlıların Varto'ya gelişine dair; öncesinde VartoBingöl dağlarını yaylak olarak kullandıkları, kışın MardinHalep tarafina gittikleri ve 19. yüzyıldan itibaren ise artık giderek buralardaki Ermeni ve Varto merkeze yakın Kızılbaş köylerine yerleşip hâkimiyet sağladıkları ifade edilir. $^{2}$ Bununla da bilhassa 19. yüzyılın sonundan itibaren Hormek ile Cibran'ın çeşitli ezbetleri (kol) arasındaki arazi anlaşmazlıkları ve bilhassa Cibran'ın Hamidiye Alayları'na mensup kollarının bölgedeki şiddet pratiklerinden ötürü iki aşireti karşı karşıya getirdiği anlaşılır (Kamil Fırat ile kişisel görüşme). Bununla beraber Hormek gibi bölgedeki Cibranlılar ile arazi anlaşmazlıkları yüzünden karşı karşıya gelen bir diğer Kızılbaş aşiret de Lolan'dır (DH.ŞFR. 26016, 28 Nisan 1317/11 May1s 1901; DH.MKT. 2495-41, 26 May1s 1317/8 Haziran 1901).

\footnotetext{
${ }^{1}$ Firat da (1961: 56-60, 80) yüzyılları farklı verse de sıralama açısından benzer bir görüş bildirir. Buna göre Avdelan/Abdalanlılar hicri 9. yüzyıl (miladi 15 yüzyıl), Lolanlılar 10. yüzyıl (miladi 15-16. yüzyıllar) ve Hormekliler ise 11. yüzyılda (miladi 17. yüzyıl) Varto'ya gelmişlerdir.

${ }^{2}$ Aytaş, 2010: 175. Bugün Sünni Kürtlerle meskun Qerqerut ve Leylek köylerindeki çeşme adlarının hala geçmişteki Lolan aşiret ağalarının adlarıyla anılması bu köylere başlangıçta Lolanların yerleştiğini ve güç dengelerine bağlı olarak buraları zamanla terk ettiklerini göstermektedir (Kamil Firat ile kişisel görüşme).
}

Hadiselerin cereyan ettiği alan Varto olunca, bölgenin tarihsel olarak demografik özellikleri kadar "etnik" ve dini yapısı da önem kazanır. Zira bu gibi özellikler tarihin birçok döneminde insan ve toplumsal örgütlenme biçimleri üzerinden şekillenen ilişkilerde belirleyici bir öneme sahip olmuştur. Ya da temel bir unsur olmasa bile tarihsel serüvenin genel akışı içerisinde sürecin işleyişine etki eden, katalizör özellikli bir yapı sergilediği söylenebilir. İşte tam da bu minvalde konuşulan dilden sahip olunan kimliğe değin Varto, tarihi boyunca bir çok etnik ve dini gruba mensup toplulukları barındıran kompleks bir yapıya sahip olmuştur. Bunlar arasında Kürt, Ermeni, Türk, Çerkes toplulukları ile bilhassa Kürtler arasında da Kurmanc ve Kırmanci (Zazaca) konuşan Sünni ve Kızılbaş-Alevi inançlara sahip iç farklılıklar söz konusudur. Hatta Varto'daki Kürtler arasındaki ayrışmanın da etnisite ve dilsellikten ziyade dinsel olduğuna dikkat çekilecektir (Gedik, 2019: 225 ve devamı). Fakat bu durum dil aynı olsa da dinsel farklılıkların da bir üst başlık olarak etnik farklılaşmalara neden olabileceğini göz ardı ettiği için eksik ve de tartışmalıdır.

Böyle olunca bölgedeki Alevi aşiretlerin hangileri olduğu ön plana gelir ki bunlar şu şekildedir: En büyükleri Hormek ve Lolan olmak üzere Avdelan, Klausiyan ve Kımsoran. Söz konusu aşiretler içinde sonuncusu Kurmanci diğerleri ise çoğunlukla Kırmanci yani Zazaca konuşurlar (Gedik, 2019: 232,239). Bunlar içerisinde de -çalışmamız ile alakalı olarak- Hormek aşireti Varto, Erzurum, Kars, Bingöl, Sivas, Erzincan ve Dersim'e uzanan geniş bir alan içerisinde yayılım göstermektedir. ${ }^{3}$

Mesele, spesifik düzeyde Zeynel Efendi örneğinden yola çıkarak Hormek ve Cibran ile birlikte Hormek ve Osmanlı Devleti ilişkilerinin aşiret içi anlatısına geldiğinde ilk akla gelen isim Mehmet Şerif Firat olur. Kendisi Zeynel Efendi'nin kardeşi Ali'nin oğludur (Kamil Fırat ile kişisel görüşme). $\mathrm{Bu}$ açıdan, genel olarak Varto tarihi özelde ise bölgedeki Kızılbaş aşiretlerin diğer civar inanç, aşiret ve Osmanlı Devleti ile ilişkilerine dair aşiret içinden kaleme alınan ilk yazılı kaynak ona aittir. Fırat, 1945 yılında tamamlanarak 1948 'de ilk baskısı yapılan ve hemen akabinde 1961 yılında Doğu Illeri ve Varto Tarihi adıla Cumhurbaşkanı Cemal Gürsel'in sunuşuyla yayınlanan eserinde, Cibran ile Hormek aşiretleri arasındaki sürtüşmelere yer yer temas eder (Fırat, 1961). Buna rağmen esere hâkim havanın, tamamen yazarın kişisel bilgileri ve yaklaşımları olduğu söylenebilir. Öyle ki Fırat, daha öncesinde kaleme aldığı kitabını (Doğu İllerimiz ve Varto) doğu illerinde dağıtılmak üzere 1946 yılında dönemin başbakanı Şükrü Saraçoğlu'na sunmuş ve başbakanlık da değerlendirilmek üzere Türk Tarih Kurumu'na önermiştir. Buna rağmen kurum, başkan Şemseddin Günaltay imzasıla Başbakanlık Özel Kalemi'ne gönderdiği cevabında, eserin "hiçbir ilmi vasıf taşımadığı ve müellifin kendi müşâhedelerine dayandığı" gerekçesiyle basılmasını uygun bulmayacaktır (BCA. 30-1-0-0-42-249-7). Benzer bir kanaat Kamil Fırat tarafindan da dile getirilip, Mehmet Şerif Fırat'ın "Hormek içi ilişkileri yanlış aksettirmekle

\footnotetext{
${ }^{3}$ Ayrıntılı bilgi için bkz. Jandarma Umum Kumandanlığı, 2010: 106-107; Ali Kemali, 1932: 188, 191, 376-377, 381, 384, 387; Çalıșlar 2010: 43, 45, 86, 127, 146, 283; Bogos Natanyan, 2015: 157; Firat, 1968: 1; Kocadağ, 1992: 217; Bulut, 2013: 144, 148, 382, 394-395, 399, 404. Bingöl ve Muş mıntıkalarındaki Hormek köyleri için bkz. Aytaş, 2010: 178-179.
} 
beraber bölgedeki Alevilerin tarihini Hormek, Hormek'in tarihini Feran, Feranlıların tarihini ise kendi Tâl ailesinden ibaret görerek, diğer Hormek kollarını görmezden geldiği” şeklinde dile getirilmektedir (Kamil Frrat ile kişisel görüşme). Bununla birlikte eserin bizce de tartışmalı olan bakış açısı ve içerdiği verilerine rağmen, ${ }^{4}$ en azından yerel düzeyde ve bilhassa Hormek içinden bir kişi tarafından ele alınmasının, aşiret içi anlatılar ve aynı şekilde dışa karşı içerde inşa edilen aşiret asabiyesinin pekiştirilmesinde sözlü tarihin işlevselliğine dair bir takım ipuçları sunduğu inkâr edilemez. Aynı şekilde Mehmet Halit Frrat da Mehmet Şerif Firat benzeri bir anlayışla kaleme aldığ hatıratında benzer bir yaklaşım sergiler (Fırat, 1968).

Hamidiye Alayları'nın Sünni yapısı gözetilerek, Varto'daki Sünni Kürt aşiretlerin bölgedeki Alevilere uyguladığı baskı ve şiddetin payı üzerinden Varto Alevi kimliğinin oluştuğu dile getirilse de (Gedik, 2019: 230) bu tür iddialara ihtiyatla yaklaşmak gerekir. Zira aşiretler içi ve arası dengeler bir bütünsellik içerisinde dönemin konjonktürel yapısı ile birlikte okunduğunda Hamidiye Alayları'na mensup Sünni aşiretlerin uyguladığı şiddetin çok yönlü olduğu anlaşılır. Bundandır ki bahse konu şiddet sadece Alevilere yönelik olmayıp -tabi bu saldırılarda inancın ötekileştirici ve motive edici bir unsur olarak ön plana getirilmiş olabileceği de unutulmadan- aynı Sünni aşiretler hem kendi içlerinde hem de civardaki diğer Sünni aşiretlere şiddetlerini yöneltmişlerdir. ${ }^{5}$

İki aşiret arasındaki ilişkilerin bir Kızılbaş-Sünni çatışması üzerinden ele alınması sözlü kültürün dile getirdikleriyle de pek uyuşmaz. Buna göre bilhassa Hormek içi kolların birbirlerine rakip oldukları gibi bu rekabette kendi ellerini güçlendirmek için Cibran aşiretinin farklı kollarıyla dayanışma içerisine girdikleri ifade edilir. Böylece Hormek'in Feran kolu Cibranlı Halilanlar, Pircanlar ise Cibranlı Teymüranlar ile dostane ilişkilere geliştirir. ${ }^{6}$ Zira Hormekli Selim Ağa'nın da Cibran ile Hesenan aşireti arasındaki çatışmada Cibranlıların yanında yer aldığ Cibranlıların Halilan kolunun ağası Mahmut Paşa'nın ölümünde de Hormekli Pircanlar ile Cibranlı Teymüranlıların parmağının olduğu dile getirilmektedir. Benzer bir iddia Zeynel Efendi'nin babasının ölümünde, Selim Ağa'nın Pircanlı nahiye müdürü Hüseyin Ağa'yı aşağılamasının ve onun da Cibranlı Teymüranlıları teşvik etmesinin rolü üzerinden dile getirilir. Aynı şekilde Zeynel Efendi de benzer bir tutumla Cibran arası çelişkilerden faydalanacaktır. İki aşiret arasındaki bu karışık ve komplike ilișkiler, 1910'lu yıllarda Cibran ve Hormeklilerin ittifak kurup Rus ve Ermeni kuvvetlerine karşı savaşmaları ve aynı şekilde karşılıklı olarak kız alıp-verip, yer yer de kirvelik tutmalarında kendini göstermiştir (Fırat, 1961: 102, 109 vd; Turabi ve Kamil Firat ile kişisel görüşmeler). ${ }^{7}$ Bahse konu aşiretlerin kolları arasındaki ittifak hadiseleri

\footnotetext{
${ }^{4}$ Fırat'ın (1961: 7 vd.) çalıșmasında ağır basan ideolojik tutum, Kürt diye bir topluluğun olmadığı ve bunların "dağ Türkü" olduğunu ispatlama arayışıdır.

5 Bu hususla ilgili Başbakanlık Osmanlı Arşivi’nde birçok belge mevcuttur. Ayrıca bkz. Tepeyran, 1998: 435, 440-441, 532-534; Fırat, 1961: 99. Ayrica bkz. Cakmak, 2019: 426.

${ }^{6}$ Cibran'ın üç kolu vardır: Halilan (Haliller), Timuran (Timurlar) ve Maksudan (Maksudlar). Akt. Aytaş, 2010: 175.

${ }^{7}$ Selim ismi; Kızılbaş-Alevi bir aşiret olarak Hormek tarihinde (Osmanl1Safevi ilişkilerindeki rolünden ötürü Kızılbaşlarca pek de müspet yaklaşılmayan Yavuz Sultan Selim'den ötürü) yer yer kullanılmıştır (Fırat, 1968: 89, 103; Kamil Fırat ile kişisel görüşme).
}

dönemin Osmanlı belgelerine de yansımıștır (DH.TMIK.M. 244-25, 5 Temmuz 1319/18 Temmuz 1903), 12 Şubat 1320 (25 Temmuz 1905). Bu da her iki aşiret kolunun kendi içlerindeki hâkimiyet mücadelesinde diğer aşiretin kollarıyla ittifak kurup, güç devşirmeleri ile alakalı bir duruma işaret eder. Buna rağmen diğer birçok yerde olduğu gibi kendi bölgelerinde hâkim iki aşiret olarak Cibran ile Hormek arasındaki anlaşmazlıkların sonu yer yer ölümlerle biten çatışmalara neden olduğunu da unutmamak gerekir (Firat, 1961: 98 vd.).

Zeynel Efendi'nin hikâyesini de iki aşiret arasındaki bu ilişkilerden ayrı değerlendirmek pek mümkün değildir. Bu da her ne kadar bireysel bir figür olarak Zeynel'in karizmasını ön plana getirse de içinde bulunduğu koşullar itibarıyla Cibran ile Hormek ilişkilerinin onun "kişisel hikâyesini" nasıl etkilediğine işaret etmektedir

\section{Zeynel'in Sözlü Tarihteki Yeri}

Zeynel Efendi, başlangıçta bir Ermeni köyü olup, sonrasında mensubu olduğu aşiretin Feran kolunun/ailesinin kontrolüne geçen Kasıman Köyü'ndendir (şimdiki adı Köprücük'tür). Bu esnada da ailenin en büyüğü İbrahim, Memıl, Zeynel, Resul ve Veli'nin babası "Talo" mahlaslı Ali'dir (Fırat, 2000). Bahse konu İbrahim (İbo Şur/KızılKırmızı İbrahim) ise Zeynel Efendi'nin babası olup, tıpkı oğlu gibi anne tarafından Karerli'dir (Turabi ve Kamil Fırat ile kişisel görüşmeler; Kıran, 2019: 31).

Zeynel çok eşli İbrahim'in (anlatımlara göre yedi evlilik yapmış ve bu evliliklerden sekiz erkek ve iki kız olmak üzere on çocuğu olmuştur $)^{8}$ küçük eşi Karerli İbrahim Ağa'nın kııı Bese/Besra'nın 1870'lerde (kuvvetle 1877) doğan ilk çocuğu olup, ${ }^{9}$ hikâyesi de ilk kez, babasının katıldığı ve kirveleri olan bir Ermeni köyünde gerçekleştirilen köydeki çocukları okula gönderme hareketliliğiyle başlar. Zira İbrahim burada, Ermeni çocuklarının okullu olmalarından ötürü oğlu Zeynel'i de okutmaya karar verir. Bunun için de ilk iș olarak kendisi ile görüştüğü Gımgım yani Varto Kaymakamı'nın telkinleri sonucu oğlunu Harput'taki yatılı okula kaydeder (Kamil Fırat ile kişisel görüşme; Kıran, 2019: 17-36). ${ }^{10}$ Burada dikkat çekici bir ayrıntıyı kaydetmek gerekir ki o da Hormek aşireti içerisinde adı resmi belgelerde de sıklıkla ön plana çıkan Selim ile İbrahim'in amca çocukları olmasıdır. Buna göre Selim'in babası Ağa ile Zeynel'in babası İbrahim Ali Talu'nun çocuklarıdır (Turabi Fırat ile kişisel görüşme).

Zeynel'in Harput'taki okulda eğitim görmeye başladığı yıllarda, Varto'da, merkezi Erzincan olup Zeki Paşa önderliğinde kurulmakta olan Hamidiye Alayları ile ilgili bir hareketlilik başlar. Bu alaylara kabul edilen aşiretlerin başında ise uzun yıllar Hormeklilerle anlaşmazlıklara sahip olan Cibran aşireti gelmektedir ki, söz konusu aşiretin alaylara dahiliyetinin getirdiği devlet güvencesi ve

\footnotetext{
${ }^{8}$ Bkz. Firat, 2000.

${ }^{9}$ Zeynel dışında Bese'den doğan diğer çocuk Cındi'dir. Babaları aynı olup anneleri farklı olan diğer kardeşleri ise şu şekildedir: İbrahim'in Veli Ağa'nın kızı olup adı bilinmeyen bir eșinden Veli ve acımasızlığıyla bilinip sonrasında babasının diğer evliliğinden olan kardeşi Ali'nin oğlu, yeğeni Mehmet Şerif Fırat'ı öldüren Halil (Helo) ile kız kardeşleri Gewez; Şerife'den sadece Ali adlı kardeşi, Behıj'dan ise Hasan, Kamer, Bego ve Frinca doğmuştur (Kamil Frrat ile kişisel görüşme).

${ }^{10}$ Kıran'ın (2019: 36) romanında Zeynel'in okula kayıt tarihi 5 Eylül 1888 olarak not düşülmüştür.
} 
silahlanması diğer topluluk ve aşiretler kadar Hormeklileri de tedirgin eder. Bununla birlikte meselenin, sadece Cibran ile ilgili de olmayıp, devletin hiçbir Kızılbaş aşiretini alaylara katılım hususunda davet etmemesiyle de alakası vard1 (Kıran, 2019: 53). Bu da alayların tamamen Sünni inanca sahip Kürt aşiretlerinden oluşturulduğunun işaretidir ki bunu ilerleyen satırlarda bizzat Selim Ağa'nın Hormek aşireti adına alaylara kabulleri için Yıldız Sarayı'na gönderdiği telgraf ve akabindeki cevaptan anlayabilmek mümkündür. Sözlü anlatımlara göre aynı Selim Ağa benzer bir talebi de Zeki Paşa ile yüz yüze görüşmek adına Erzincan'a gidişiyle göstermiştir (Kıran, 2019: 171-176).

Hamidiye Alayları'na mensup aşiretlerin civardaki ahaliye yönelik birçok yerde gerçekleştirdikleri baskıdan Varto'daki Hormek ve Lolan aşiretleri de payına düşeni alacaktır. $\mathrm{Bu}$ da alaylara mensup aşiretlerin iç nizam ve güvenliği sağlamaktan ziyade, giderek kendilerinin ciddi bir tehlike haline geldiklerini ve bundan ötürü alayların dışında kalan ya da kabul edilmeyen diğer Sünni, Kızılbaş ve Ezidi/Yezidi gibi Kürtlerle birlikte Hristiyanların da ciddi endişeler duyduklarını gösterir. Bu da doğal olarak dışarıda kalan söz konusu grupların kendi olanakları ile olası bir saldırıya karşı silahlanmalarını neden olacaktır (Kıran, 2019: 61-64).

Hamidiye Alayları'nın bilhassa Cibranlılara sağladığ prestij ve güç, İstanbul'da kurulan Aşiret Mektebi'ne aşiret çocuklarının kabulüyle de pekişmiştir (Kıran, 2019: 65-66). Bunlar arasında adından bilhassa ilerde sıklıkla söz edilecek olan Cibranlı Halit Efendi de bulunmaktaydı. Fakat bu mekteplere, alaylardan farklı olarak, Dersim gibi bölgelerden gönderilen Kızılbaş çocuklarının kabul edildiği unutulmamalıdır (Çakmak, 2019: 430-433).

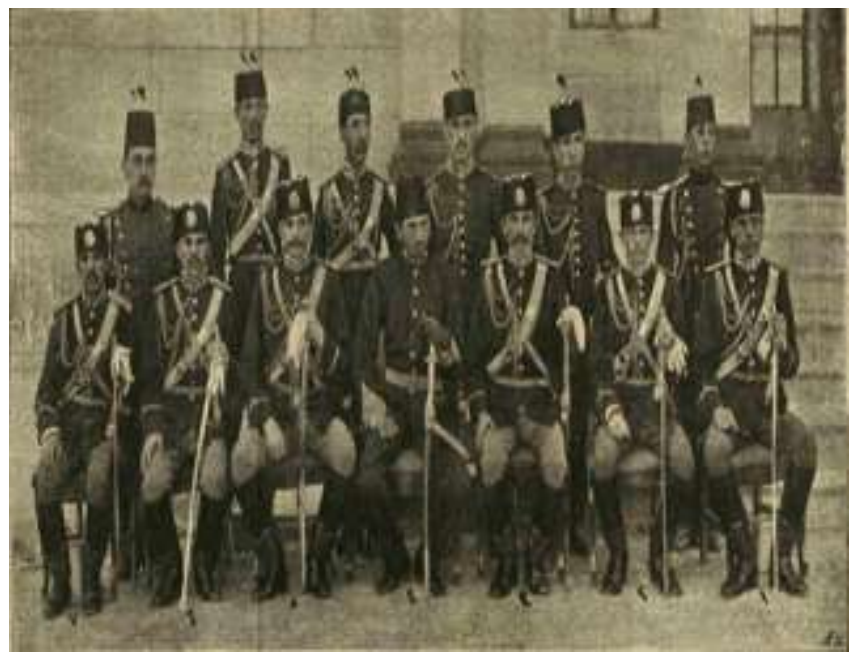

Foto 1- Așiret mektebine gönderilen çocukların mezuniyetlerinde çekilen fotoğraf. Sağdan sola oturanlardan ikinci kişi Cibran Aşireti'nden Halit Efendi'dir. Bkz. Servet-i Fünûn, 1314: 244.

Hamidiye Alayları'nın kuruluşu ile birlikte Hormek ve Cibran'ın kimi kolları arasındaki ilişki giderek gerilimli bir hal aldı. Bu nedenledir ki aldığı eğitimden ötürü Zeynel Efendi babası İbrahim tarafindan Varto kaymakamı ile görüşmeye gönderilmiştir (Fırat, 1961: 100; Kıran, 2019: 80-84, Turabi Fırat ile kişisel görüşme). Bununla birlikte iki aşiret arasındaki ilişkinin tamamen hasmane ve gerilimli olduğu değerlendirmeleri de pek doğru değildir. Zira iki aşiretin ve bilhassa Cibran içindeki güç dengelerinden ötürü yer yer kimi aşiret ağalarının Hormekliler ile dostane ilişkiler geliştirdikleri olmuştur. Benzer şekilde iki aşiret arasındaki ilişkilerin yanı sıra, II. Abdülhamid (1876-1909) döneminde sıklıkla dile getirilen "Ermeni-Kızılbaş yakınlığı ve ittifakının" aksine bizzat Kızılbaş Hormeklilerin Ermeni köylerine saldırdıkları da görülecektir ki bunun başını da Hormekli Selim Ağa çekmiştir. Bu bakımdan Selim giderek aşiret içerisinde parlayan bir kişilik haline gelerek hem devlet görevlisi hem de Cibranlıların yeğeni olan Uskıran Nahiye Müdürü Hüseyin Bey'i dövüp, devlet adına toplanan para ve vergilere el koymasıyla adını daha da ön plana çıkarır. Selim'in bu davranışı devlet, Cibranlılar ve Hormeklilerin bir kolu olan Pircanların tepkisiyle karşılaşır. $\mathrm{Bu}$ nedenle kendisini takip için gelen ve içinde asker, Hamidiye Alay mensupları ve Hormekli Hüseyin Bey ile adamlarının olduğu toplu bir kuvvetle girdiği çatışmadan ötürü Zeynel'in babası İbrahim Ağa ile Hasan ve Cındi adlı çocuk yaştaki iki oğlu ve on komşusunun Kortegul'da öldürülmesine (rumi 1310/miladi 1894) neden olur. Bu çatışmadan yaralı olarak kurtulan tek kişi, bu esnada henüz buluğ çağında olan, Zeynel'in kardeşi Ali olur. Bu süreç en nihayetinde Zeynel Efendi'nin okulu birakarak ailesinin yanına dönmesine neden olacaktır (Fırat, 1961: 101; Kıran, 2019: 85-90, 95-103, 108-111; Turabi Frrat ve Kamil Frat ile kişisel görüşme).

Burada bir diğer ayrıntıya daha dikkat çekmek gerekir ki o da Hamidiye Alayları içindeki ilişkiler ve hatta aynı aşiret mensubu Hamidiyeliler arası münasebetlerin muhtevasıdır. Bunun için en azından bütün Hamidiye Alayları mensuplarının civarlarına aynı oranda saldırmadıkları gibi kendi aralarında da benzer dostane ilişkileri geliştirmedikleri unutulmamalıdır. Buna bir örnek olarak bilhassa Varto bölgesindeki iki Hamidiye Alayı'nın arasının açık olup, çevrelerine rahatsızlık verme hususunda birinin geri dururken diğerinin saldırgan bir tutum takınarak Ermeni mallarına yönelik saldırılar gerçekleştirdiği ifade edilir. $\mathrm{Bu}$ da alay mensubu gruplar içerisinde çeşitli çatışmalara neden olmuştur. $\mathrm{Bu}$ kavgalar neticesinde Cibranlı Halit Bey'in babası Mahmut Paşa 1898 yılında öldürülecektir (Fırat, 1961: 102; Fırat, 1968: 102; Kıran, 2019: 170). Diğer yandan benzer bir durum da Hormek aşireti içinde göze çarpar. Zira aşiretin Feran koluna mensup Selim Ağa ile aşiretin Pircan koluna mensup olup, aynı zamanda yeğenleri olduğu için Cibranlıların Teymüran kolunun desteğini arkasına alan nahiye müdürü Tatanlı Hüseyin Bey'in çatışmaya varan münasebetleri, dinsel aidiyetler üzerinden bir kutuplaşma anlatısının sorunlu olduğunu gözler önüne sermektedir. $\mathrm{Bu}$ da aşiret içinde ve aşiretler arasındaki ilişkilerde ihtiyaç halinde dinsel söylemin de araçsallaştırıldığı bir güç ve iktidar alanı ve çatışması yaratmıştır. Bu çatışmalarda dinsel söylem ihtiyaç halinde devreye sokulabilen ya da geriye itilebilen bir meşrulaştırıcı güç olarak işlev görecektir (Kamil Fırat ile kişisel görüşme).

Zeynel, okulu bırakarak dönmesiyle ailenin reisi olarak üzerine düşen sorumlulukları yerine getirmekle meşgul olmaya başlar. Bununla beraber bilhassa aldığı eğitimin aşireti içerisinde kendisinden saygıyla bahsedilmesi ve danışılan kişi olması üzerinde büyük bir etkisi olur. Aynı şekilde, elde ettiği söz konusu statü ona evliliğin yolunu da açacaktır ki bunun için ilk icraatları arasında diğer bir Kızılbaş-Alevi köyü olan Muskan Köyü'nden Mahmut oğlu 
Ali'nin kızı Fatma (Fatı) ile evlenecektir. ${ }^{11}$ Bu evlilikten de Zeynel'in babasının anısını yaşatmak adına adını İbrahim koydukları ve hemen sonrasında hastalıktan ötürü ölecek çocukları dünyaya gelir. İbrahim'in ölümünden sonra da Ali Haydar (Dikmen) ve Hediye adlı çocukları doğar (Turabi ve Kamil Fırat ile kişisel görüşmeler; Kıran, 2019: 39, 112-119, 160, 162, 262).

Aşiret içerisinde önemli bir yere gelmenin hem Zeynel'in kendi duyguları hem de aşiretinin prestiji açısından beklenen bir karşılığı/sonucu olur: Babasının intikamını almak ki beklenildiği gibi de olur. Bu durum Zeynel'in adının giderek ön plana gelmesi ve kendisinden övgüyle bahsedilmesine sebep olacaktır (Kıran, 2019: 125-131). Böylelikle Zeynel açısından yaşamının bir diğer safhası olarak firar dönemi başlar. $\mathrm{Bu}$ da devamında karıştığg olaylarla birlikte Osmanlı resmi söyleminde "şakî" olarak nitelendirilmesi ve takibatını beraberinde getirecektir. Bu takibat neticesinde de birçok kere asker ve Hamidiye üyeleriyle çatışmaya girer (Fırat, 1968: 69-70, 76-77; Kıran, 2019: 163-166, 183-184). Adı giderek ön planda olsa da Hormek içinde ağalık statüsü ile varlık gösteren kişi Selim Ağa olup, Zeynel ise kardeşi Veli ve yanındaki silahlı adamlarıyla artık dağlarda barınan bir firari ve aşiretinin silahlı gücünü oluşturur (Fırat, 1961: 101 vd; Kamil Frrat ile kişisel görüşme).

Zeynel bu dönemden itibaren devletin artık her yerde peşine düştüğü bir kişidir. Kendi ve yanındaki arkadaşları (bunlar arasında Milan aşiretinden Selime Xişman ve Xelile Dilferac bulunmaktadır) için durum devlet cephesinde bu şekilde seyrederken, halka verdikleri destekler ile giderek bölgede yerel kahramanlar haline gelmeye başlarlar (Kıran, 2019: 135-152, 157). Tabi burada günümüze kadar süregelen bu "mit" ya da anlatıların, halkın tahayyül dünyası ve sözlü kültürün etkisiyle ne denli şekillendiğini de unutmamak gerekir.

Zeynel'in firari yıllarında aşiretin önderliğini yürüten Selim Ağa'nın -yukarıda da ifade edildiği gibi- Erzincan'da Zeki Paşa ile olan görüşmesinden sonra Hormekliler ile devlet arasında bir yumuşama süreci başlayacak ve bu da Selim'in kardeşi Mustafa'nın Uskıran Nahiyesi'ne müdür olmasıyla devam edecektir (Kiran, 2019: 178-180). Bu da bilhassa Hormeklilerin Feran kolunun güçlenmesini istemeyen alay mensubu Cibranlıların Teymüran kolu tarafından kabul edilmeyip, Uskıran'a, karşılaştıkları mukavemetten ötürü başarısız bir saldırıda bulunmalarına neden olur (Kıran, 2019: 188).

İcraatlarıyla adı giderek ön plana gelen Zeynel, artık başta saray olmak üzere giderek devlet ve Hamidiye Alayları'nın takibine girmiştir (Frrat, 1968: 102-104, 107). Bu nedenle kendisinden ötürü aile efradına yönelik artan baskılar ve aynı şekilde firari olmanın verdiği zorluklardan kurtularak yeniden normal hayatına dönmek adına affı için İstanbul'a

\footnotetext{
${ }^{11}$ Ali Ağa ile Zeynel Efendi'nin babası İbrahim Ağa amca çocukları olup, aynı şekilde Zeynel'in annesi ile Ali Ağa'nın eşi Hatun'un da amca çocukları olmalarının bu evliliği kolaylaştırıcı bir rolü olmuştur. Diğer yandan Muskanlı Ali Ağa'nın ardıllarının grup hafızasında Kıran'ın (2019) kitabındaki iddiaların tersini işaret eden güçlü bir karşı anlatı mevcuttur. Buna göre, Ali Ağa; Zeynel ve kardeşi Veli'nin kızlarına olan ilgisini fark edince, onları akrabaları olan Resul Ağa'nın torunlarıyla nişanlandırır. Bununla da istenmeyen olası bir evliliğin önüne geçeceğini düşünür. Ancak Ali Ağa'nın eşi Hatun'un yardımıyla kızları Fatık Zeynel, Nazlı ise Veli ile kaçar. (Kamil Fırat ile kişisel görüşme).
}

gider. Amacı, adet olunduğu dile getirilen, "gizlice saraya adım atarak, sultandan affını" istemektir (Kıran, 2019: 197206). ${ }^{12}$ Fakat bunu gerçekleştiremeden burada kendisini tanıyan eski bir Ermeni muhbirin ihbarı üzerine tutuklanarak eşkâlinin tespiti için Gımgım yani Varto'ya gönderilir. Akabinde de Zeynel bir yolunu bularak Erzincan'da askerin elinden kaçar. Bu firar esnasında da Zeryawi adındaki Türkmen köyünde köylüler tarafından üzerindeki elbiselere varıncaya değin soyguna uğramıştır ki daha sonrasında bu davranıştan ötürü intikam olarak adı geçen köyün hayvanlarını gasp eder (Kıran, 2019: 207-216, 221-224, 228-235; Turabi firat ile kişisel görüşme).

$\mathrm{Bu}$ esnada Hormek ve Cibranlılar arasındaki ilişkilerin arazi ve yayla anlaşmazlıkları yüzünden mevcut olumsuzluklarıyla devam edecektir. Bunlar arasındaki en nihai nokta ise Selim Ağa'nın 1905 yılında Cibranlıların Karlıova kolu olan Mahsutanlar tarafından öldürülmesi olur (Frrat, 1961: 104). ${ }^{13}$ Bunun üzerine Hormekliler de Zeynel öncülüğünde, hem Selim'in cesedini hem de intikamını almak üzere Cibranlıların Maksudan kolunun meskun olduğu Kargapazar adlı köye saldıracak ve böylelikle karşıllklı olarak adam öldürme ve talan süreci başlayacaktır (Frrat, 1961: 104-105; Firat, 1968: 76-77, 102; Kıran, 2019: 254-260). Burada önemli bir husus, sözlü kültürde anlatıldığı kadarıyla, Zeynel'in kısasa kısas bir yağma yaptığı yönündedir (Kamil Frrat ile kişisel görüşme). Buna rağmen bu anlatının aksine, eşkıyalığın da bir ekonomipolitiğinin olduğu düşünülerek, bunun kısasa kısas bir yağmalamadan ziyade kendi ve yanındakilerin varlıklarını sürdürmek adına bir zorunluluk olduğu da düşünülmelidir (Hobsbawm, 1995: 71).

Hadiseler bu şekilde cereyan ederken bölgedeki Hamidiye Alayları açısından önemli bir gelişme yaşanır. Aşiret Mektebi'nde okuduktan sonra Harbiye'de tahsilini tamamlayan Cibranlı Halit Bey miralaylık rütbesi ile Hamidiye Alay komutanı unvanıyla bölgeye gönderilir (Kıran, 2019: 250). Daha önce de belirtildiği gibi kendisi, Hormek ve Cibran ilişkilerinde mutedil ve barışçıl bir tutum takınan Halilan kolunun ağası Mahmut Paşa'nın oğluydu. Bu nedenle Halit Bey'in, gerek İstanbul'daki yaşantısı süresince geliştirdiği bilinç gerekse babasından devraldığı anlayıştan ötürü kendi aşiret asabiyesinin daha da üstünde bir anlayışla hareket ettiği belirtilir. Bu açıdan sonraki yaşantısında da bu doğrultuda hareket eder. ${ }^{14}$ Böylece Selim'in öldürülmesi üzerine iki aşiret arasında tırmanan ortama da müdahale edip, geçici süreliğine de olsa çatışmaları durduracaktır (Kıran, 2019: 260).

Firari olmanın verdiği dezavantajla sürekli mekân değiştiren Zeynel açısından en büyük hadise eşi Fatma ile birlikte kaldıkları Seyit İbrahim mezrasında Fatma'nın 1906 yılında öldürülmesi olur. Başından itibaren kızları Fatma ile Naze'yi diğer iki kardeş Zeynel ve Veli'ye verme

12 Kıran'ın anlatımından, Zeynel'in İstanbul'a gidişi Ermenilerce Abdülhamid'e gerçekleştirilen başarısız suikastın bir yıl sonrasıdır ki bu da 1905 yılında gerçekleştirilen bombalı suikasttır.

${ }^{13}$ Bazı anlatımlar Selim Ağa'nın bir meczup tarafindan öldürüldüğünü dile getirse de öldürülmesi sonucunda ölüsünün başlangıçta rehin alınmasının bunun bir tesadüf olmadığını gösterir (Kamil Fırat ile kişisel görüşme).

${ }^{14}$ Halit Bey Hormekliler içinde "son derece inançlı ve ahlaklı bir olarak tasvir edilir. Fakat aynı şey Cibranlı Kasım için anlatılmaz [kendisi Şeyh Said'in bacanağı olup, Halit Bey'in de damadı olup Cıbranlıların Teymüran koluna mensuptur]. Turabi ve Kamil Firat ile kişisel görüşmeler. Ayrıca bkz. Fırat, 1968: 18. 
taraftarı olmayan Ali’nin, firari olan damatlarının köylerine bu geliş gidişlerinden rahatsız olduğu ve bu nedenle de sürekli asker tarafından sorgulandığı belirtilir. Sonuçta da damatlarının yakalanması ya da ölümleriyle bu sürecin sonlanacağı düşünülür (Kamil Firat ile kişisel görüşme). Böylece gerçekleştirilen ihbar neticesinde meydana gelen çatışmada bacağından yaralanan kızları Fatma Zeynel'in talimatı ile kardeşi Veli tarafından öldürülür (Fırat, 1961: 106; Firat, 1968, 103; Kiran, 2019: 261-269). ${ }^{15}$ Sözlü anlatımlara göre Fatma'nın, yarasının ağırlığından ötürü eşi Zeynel'e "efendi benim katlim sana helaldir, beni askere verme" demesi üzerine öldürüldügü belirtilir (Turabi Fırat ile kişisel görüşme). Olaylar meydana geldiğinde çocukları da yanlarında olup, Ali Haydar adlı oğulları henüz 3-4 yaşlarındadır. Netice olarak da Zeynel, eşinin ölümüyle, bir yıl sonra kayınbabasını öldürtecek (kimi anlatımlarda kardeşi Veli öldürmüştür) ve üzerinden çok geçmeden yeni bir evlilik yapacaktır. Bu yeni evlilikten çocukları olsa da hepsi hastalıktan ölür (Turabi ve Kamil Fırat ile kişisel görüşmeler). ${ }^{16}$

Yaşananlar Zeynel açısından kendisini daha da sıkıntılı günlerin beklediğinin habercisidir. $\mathrm{Bu}$ nedenle Sultan II. Abdülhamid'in elinde olan affının sağlanması için çeşitli arayışlara girişir. Bunun başında da sultan nezdinde itibarlı bir yere sahip olan Hamidiye Alay paşası Milli/Milan aşiretinin reisi ünlü İbrahim Paşa ile Viranşehir'de görüşüp, onu sultanın huzuruna gönderip, af beratını sultandan almaya çalışır. ${ }^{17}$

\footnotetext{
15 İhbar hadisesinde her ne kadar Fatma/Fatık'ın babasının adı geçse de esasında perde arkasında annesi Hatun'un olduğu dile getirilir. Aynı şekilde bu esnada hamile olan Fatma'nın yaralı da olmayıp, kaçamayacağ ve askerin eline düșeceği korkusuyla öldürüldüğü de ileri sürülmektedir (Kamil Fırat ile kişisel görüşme). Turabi Fırat'a göre ise Zeynel'in kayınbabası damadından ötürü gözaltına alınmıș ve Zeynel'in yerini söylemesi için zorlanmıştır. Bunun üzerine eşi Hatun'a Zeynel'in yerini söylemesi için haber gönderdiği ve bunun üzerine de Hatun'un, oğullar Mehmet Halit Fırat'1 Uskıran'daki alay komutanına göndererek Seyit İbrahim mezrasında saklanan damadının yerini ihbar ettiği belirtilir (Turabi Fırat ile kişisel görüşme).

16 Kimi anlatımlarda da Veli’nin kayınbabasını ihanetinden ötürü Zeynel'in talimatı ile öldürdüğü dile getirilir.

${ }^{17}$ K. Firat (kişisel görüşme) bu tarihin 1909 olduğunu dile getirir. Ayrıca bkz. Kıran, 2019: 271-303. M. Şerif Fırat'a (1961: 107) göreyse Zeynel jurnallerde Jön Türkçü olarak saraya ihbar edildiği için affedilmemiș, ama İttihat ve Terakki Cemiyeti'nin iktidara gelmesi ile 1908 yllında hemen affedilmiștir. Bununla birlikte Zeynel'in İbrahim Paşa ile olan görüşmesine bu esnada henüz küçük olan oğlu Ali Haydar'ı da götürdüğü ve paşanın çocuğu Zeynel'den ağırlığı kadar altın verme karşılığında istemesine rağmen Zeynel'in bunu kabul etmediği belirtilir (Turabi Frrat ile kişisel görüşme).
}

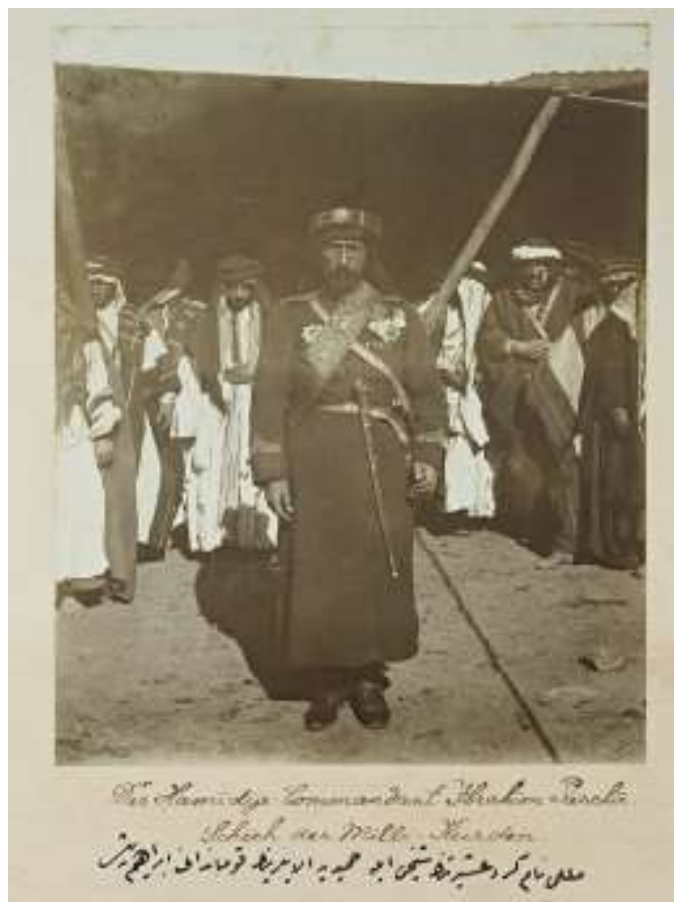

Foto 2- Milli Așireti’nin șeyhi ve Hamidiye Alayları kumandanı İbrahim Paşa (İstanbul Üniversitesi Nadir Eserler Kütüphanesi)

Buradaki ilgi çekici husus Zeynel'in Varto'dan çıkarak neden Urfa'ya kadar gittiğidir. Bu durum acaba "sadece İbrahim Paşa'nın saray nezdindeki itibarından mı yoksa Hormek ve Milan aşiretleri arasındaki dostane ilişkilere mi dayanmaktadır" sorusunu ön plana getirir. Buna göre gerek yukarıda isimleri zikredildiği gibi Zeynel Efendi'nin yanında Milanlı silahşorların olması gerekse Milan ve Hormek aşiretlerinin yakın temaslarından ötürü İbrahim Paşa isminin ön plana geldiği düşünülebilir. ${ }^{18}$ Bununla beraber Zeynel de bilhassa Urfa'da iken Milan aşiretinin sürülerini Karakeçili aşiretinin yağmasından kurtardığg için İbrahim Paşa'nın gözüne girecektir (Turabi Fırat ile kişisel görüşme).

Zeynel, affindan sonra köyü Kasıman'a yerleşerek, mütevazı bir hayata başlar. Fakat 1911 yılında kardeşi Veli yeğenleri olan Selim adlı biri tarafindan öldürülürken (Frrat: 1968: 103) bir y1l sonra da Zeynel evinin önünde gece uzaktan atılan faili belirsiz bir kurşunla yaralanarak, birkaç günlük koma sürecinden sonra yaşamını yitirir. Koma sürecinde iken, bu saldırıyı ölen eşi Fatma'nın kardeşi Begali (Bey Ali) tarafından, babası ve kız kardeşinin intikamını almak gerekçesiyle gerçekleştirildiğini dile getirir. Böylece Begali'nin şüpheli ölümünün de Zeynel'in akrabaları tarafindan intikam gerekçesiyle gerçekleştirilen bir zehirlenme hadisesinden kaynaklandığ $\breve{g}_{1}$ konuşulur (Fırat, 1968:103; Kamil Fırat ile kişisel görüşme). Bu hususta bir diğer anlatım ise, Veli'nin, kayınvalidesi tarafından yeğeni Selim ile evlenme sözü verilerek öldürtüldüğüdür Buna rağmen kayınvalide Hatun'un, Emeranlı (Onpınar Köyü) Hüseyin Ağa adlı başka biriyle evlenip ve Zeynel'i de bu kişiye öldürttüğü dile getirilir (Turabi Frrat ile kişisel görüşme).

18 Milanlılar ile Hormekliler arasındaki yakın ilişkilerin yayla münasebetleri ile güçlendiği ve biri Sünni diğeri de Kızılbaş olan iki aşiret arasında dostane ilișkilerin böylelikle kurulduğu dile getirir (Kamil Fırat ile kişisel görüşme). 
Tüm bu yaşananlar da Zeynel'i Hobsbawm'ın “sosyal eşkıya” kategorisi içerisinde değerlendirilmesini mümkün k1lar:

Sosyal eşkıya adi bir suçlu olmadığından, kanundışı olmaktan kurtulduğu zaman, doğup büyüdüğü yere topluluğun sayg1 duyulan bir üyesi olarak geri dönebilir. $\mathrm{Bu}$ konuda elde bulunan kaynaklar aynı noktada birleşmektedir. Gerçekte eşkıya halkını hiçbir zaman terk etmez. Çoğunlukla kendi köyüne, akrabalarına yakın yerlerde yaşar. Akrabaları ve köylüler ona topluluk için belli bir görevi yapıyormuş gibi davranırlar ve onu beslerler (Hobsbawm, 1995: 39).

Buraya kadar dile getirilenlerden görüleceği üzere, Zeynel'in yaşamında, babasının ölümüyle birlikte mekân ve zamandaki gelişmelerin etkisiyle bir takım temel değişiklikler yaşanmıştır. Fakat tüm bunlara rağmen onu diğer karakterlerden farklı kılan önemli bir özelliği vardır ki o da aldığı eğitimin sağladığı ayrıcalıktan ötürü "efendi" unvanıyla anılması olur. Buna göre Selim ve Halil gibi simalar "ağa", oğlu Haydar "bey", kendisi ise "efendi" olarak zikredilir. Bu bakımdan kişiler nezdinde somutlaşan üç unvanın da dönemsellik ve muhteva itibarıyla yaşanan değişim ve dönüşümün yansıması olduğunu söyleyebiliriz. Fırat'a göre de "ağa" daha eski bir adlandırma olup doğrudan klasik iktidarın yansıması, "bey" devletle görüşen ve işbirliği yapan kişi, "efendi" ise okumuş yazmış saygın bir kişiye hitap etmenin şekillenmiş hali olup, Zeynel'in sahip olduğu unvanı buna göre düşünmek gerekir (Kamil Fırat ile kişisel görüşme). Bununla beraber Zeynel'in ağa olarak adlandırılmamasında, aşiretinin lider konumundan ayrılması ve dağda yürüttüğü sürecin etkisinin olduğu da düşünülebilir.

\section{Osmanlı Resmi Söyleminde Zeynel ve Hormekli Surh-ser/Kızılbaşlar}

Sözlü tarih odaklı anlatıların da ortaya koyduğu gibi Zeynel Efendi'nin hikâyesinin kendi kadar aşiretinin tarihi açısından da önemli bir rolü vardır. Bu bakımdan genel itibarı ile sözlü kültürün özelliklerinin de göz önünde bulundurularak, söz konusu anlatının geçmişten günümüze değin farklı yön ve anlatımlarla taşındığı unutulmamalıdır. ${ }^{19}$ Bununla birlikte bizzat dönemin resmi otoritesi olarak Osmanlı Devleti'nin tutumu da Zeynel Efendi ile ilgili sözlü anlatımlarda dile getirilenleri bir yanıyla doğrularken, diğer yönden farklı bir portre çizer. Zeynel, aşireti içerisinde efendi unvanlı, yiğit ve haksızlıklara karşı duran bir kişilik olarak sunulmasına rağmen, Osmanlı söyleminde daha çok devlet otoritesine karşı gelen, gerçekleştirdiği yağma ve şekavet hadiselerinden ötürü şikâyetlere konu olan bir portre olarak sunulur. Bunun ise daha çok "nereye bakıldığından ziyade, nasıl bakıldığgı" ile alakalı bir durumdan kaynaklanmakta olup, bir yanıyla hem yerel bilgi hem de resmi söylemi örtüştüren bir alan yarattı̆ğ söylenebilir. Bundandır ki Zeynel, aşireti ve bölgedeki Kızılbaşlar nezdinde gerçekleştirdikleriyle haklı bir pratik sergilediği ve dolayısıyla şekâveti de meşru bir zemine dayandırılırken, aynı şey devlet açısından tamamen farklı ve otorite tanımaz bir profille ifade bulur. Böylece tam da bu dönemde, devletin Hormek aşiretine bakışında, resmi söylemde "şakî" ifadesi üzerinden bir popülarite kazananların başında

\footnotetext{
19 Sözlü ve yazılı kültürün özellikleri ile ilgili yapılmış muhakkik bir çalışma olarak bkz. Ong, 2012.
}

Zeynel ile Selim Ağa gelir. ${ }^{20} \mathrm{Bu}$ açıdan her ikisinin de devam eden şekavetlerinden ötürü gıyaben idam cezasına mahkûm edilip, yakalanmalarına defaten tevessül edilmesine rağmen başarısız kalınmıştır (DH.TMIK.M. 200-32, 17 Nisan 1321, 14 Rebiyûlevvel 1323/30 Nisan ve 30 Mayıs 1905). Zeynel ve döneminde aşiretinin devlet nezdindeki pozisyonu Sultan Abdülhamid döneminin Kürt ve bilhassa Kızılbaş siyasetinden münezzeh kalmaz. Bu açıdan yukarıda da bahsedildiği gibi bu dönem Hormek ve Cibran ilişkilerinde önemli bir etken olan Hamidiye Alayları'na Cibranlıların kabul edilirken Hormeklilerin liderleri Selim Ağa öncülüğünde defaten gerçekleştirdikleri başvurularının karşılıksız kaldığını gösterecektir. Bu durum Selim tarafindan Dâhiliye Nezareti'ne çekilen son telgrafta şöyle ifade edilir:

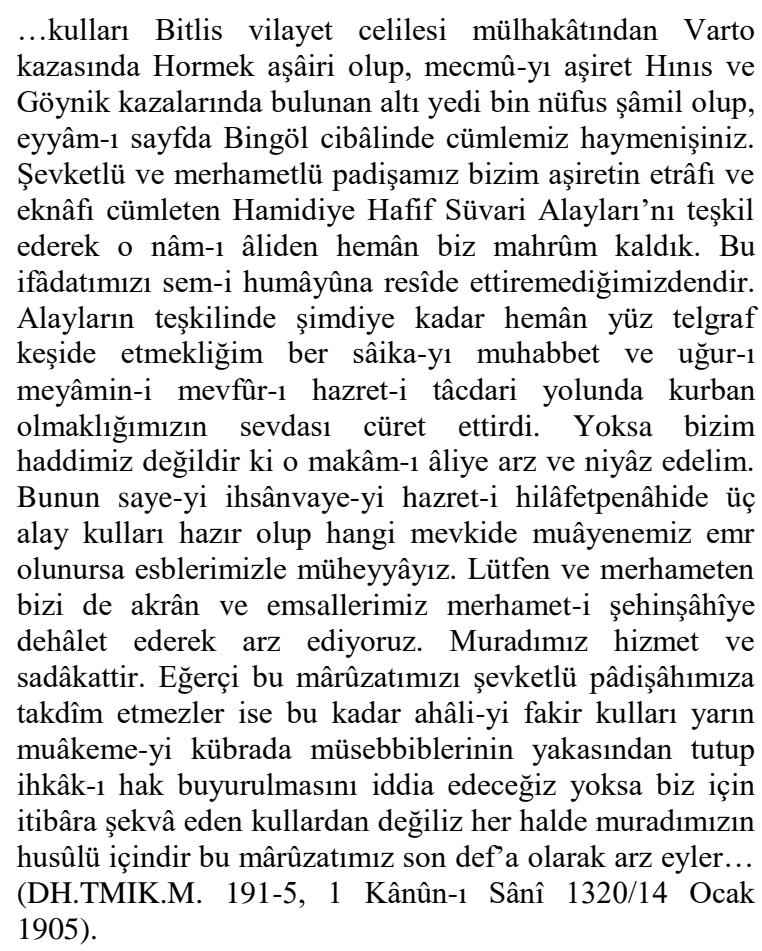

Selim Ağa tarafından defaten çekilen telgrafların karşılıksız bırakılmasının nedeni, dönemin ruhuna uygun olarak alayların daha çok Sünni Kürtlere tahsis edilmesinden kaynaklanmıştır. $^{21} \mathrm{Bu}$ da bilhassa yönetimin öncesindeki yüzyıllardan kalma Kızılbaşlara yönelik önyargı ve endişelerine dayanır. ${ }^{22}$

Tüm bunlara rağmen ve daha önce de belirtildiği gibi Hormek ve Cibran ilişkilerinin klasik bir mezhep kavgası üzerinden okunması bizzat Osmanlı arşiv belgelerinin hilafına unsurlar barındırır. Örneğin, alaylara mensubiyeti bulunmayan Varto ve Bingöl'deki Kızılbaşların Hamidiye Alayı mensubu olmayan Sünni Kürtler ile birlikte alay mensubu bey ve ağalara yönelik saldırılarda bulunarak,

\footnotetext{
20 "Hormekli şakî meşhur Selim ve Zeynel" (DH.TMIK.M. 201-30, 16 Haziran 1321/29 Haziran 1905; BEO. 2645-198304, 1, 3 Ağustos 1321/16 Ağustos 1905). Resmi belgelerde Zeynel'den sıklıkla "şakî Zeynel" olarak söz edilirken bazen de "Hormekli Zeynel", "Hormekli şakî Zeynel", "şakî Vartolu Zeynel” adlandırmalarına başvurulur. Bkz. BEO.2646-198429, 24 Temmuz 1321/6 Ağustos 1905; DH.ŞFR. 332-78, 29 Ağustos 1320/11 Eylül 1904; BEO. 2688-201552, 4 Teşrîn-i evvel 1321/17 Ekim 1905; DH.MKT. 1189-11, 21 ve 28 Temmuz 1323/3 ve 10 Ağustos 1907.

${ }^{21} \mathrm{Bu}$ hususta sadece Kızılbaşlar değil Ezidi Kürtlerin başvurusu da reddedilmiştir. Bkz. Y.EE. 139-15, 23 Mart 1892.

22 Dönemin Kızılbaş siyaseti ve algısına dair ayrıntılı bilgi için bkz. Çakmak, 2019.
} 
ölümlerine neden oldukları anlaşılmaktadır (DH.TMIK.M. 146-20, 28 May1s 1319/10 Haziran 1903). Benzer bir durum bizzat Zeynel Efendi ile Cibranlı Halit Bey'in adamlarının ortak hareketle yağma faaliyetlerine katılmaları için de geçerlidir (BEO.2646-198429, 24 Temmuz, 6 Ağustos 1321/6 ve 19 Ağustos 1905). Hatta farklı bir örnek olarak Hormeklilerin Cibranlı bir takım alay mensubu bey ve zaptiyelerin desteğini alarak diğer Cibranlılar ile mücadeleye tutuştukları da söz konusudur (DH.TMIK.M. 244-25, 31 May1s 1321/13 Haziran 1903; DH.TMIK. M. 200-32, 17 Nisan 1321/30 Nisan 1905). Bu ise yukarıda da ifade edildiği gibi daha çok Hormek ve Cibran içi farklı kolların ittifakları ile açıklanabilecek bir duruma işarettir. $\mathrm{Bu}$ gibi örnekler de meseleye inanç mevhumu ve çatışması üzerinden yaklaşmanın yetersizliğini gözler önüne serer.

Tabi burada önemli bir husus da yetkililerin Hormeklilere yönelik bakışlarında aşireti "erbâb-1 şekâvet", "Hormekan eşkıyası" ya da "Hormek eşkıyası" olarak tanımlayacak menfi bir bakış açısına sahip olmalarıdır. ${ }^{23}$ Bunda etkili olan etkenin başında sayılarının elli ile üç yüz arasında değiştiği belirtilen aşirete mensup silahlı kişinin söz konusu olması gelir ki bu da Zeynel'e işaretle eşkıya olarak dağlarda gezindiği döneme tekabül eder. ${ }^{24} \mathrm{Bu}$ nedenledir ki yer yer doğrudan aşirete göndermede bulunularak, mensuplarına yönelik askerce sık sık takibat yapılmıştır. Tüm bunlar da dağlarda hiçbir silahlı Hormeklinin bırakılmayıp, takip ve tenkillerinin gerçekleştirilmesi ve şekâvete yatkınlığı olanların da şiddetli bir şekilde tedip edilmeleri uygun görülmüştür. ${ }^{25}$ Burada Hormeklilerin resmi inanç dışında, surh-ser/Kızılbaş inancına mensup olmalarının etkisi de olacaktır. ${ }^{26}$

Hormeklilere yönelik ifade bulan resmi söylemde Zeynel Efendi bilhassa gündeme getirilmiştir. Bundandır ki gerek kendisi gerekse arkadaşları, gerçekleştirdikleri yağma ve cinayetlerden ötürü sık sık şikâyetlere konu olacaktır. ${ }^{27}$ Burada önemli bir ayrıntı da Zeynel ve yanındakilerin elli kişilik bir silahlı topluluktan oluştuğuna dair yer yer devam eden vurguların yapılmasıdır ki, bu da söz konusu sayının bir eşkıya grubu için önemli bir oran olduğunu gösterir (Y.PRK.ASK. 175-92, 24 Eylül 1317/7 Ekim 1901).

Daha önce de ifade edildiği gibi, sözlü kültürde Zeynel'in affı için, bir kez Selim Ağa'nın Zeki Paşa'dan (-ki o da bunu kabul etmemiştir) diğeri de bizzat kendisinin İbrahim

\footnotetext{
23 Bkz. DH.TMIK.M. 244-25, 17 Rebiyülevvel 1321/13 Haziran 1903; DH. SFR, 366-109, 21 Haziran 1322/4 Temmuz 1906; BEO. 2721204003, 21 ve 28 Haziran 1322/4 ve 11 Temmuz 1906; BEO.2748206090, 5 Kânûn-1 sânî 1321/3 Şubat 1906.

24 Bkz. DH.TMIK.M. 244-25, 5 Temmuz 1319/18 Temmuz 1903; BEO.2646-198429, 24 Temmuz, 6 Ağustos $1321 / 6$ ve 19 Ağustos 1905; DH.MKT. 1189-11, 21 Temmuz 1323/3 Ağustos 1907; DH.TMIK.M.20032, 5 Temmuz 1319/18 Temmuz 1903.

${ }^{25}$ Bkz. BEO. 2688-201552, 26 Eylül 1321/9 Ekim 1905; DH.TMIK.M. 200-32, 5 Temmuz 1319/18 Temmuz 1903.

26 Bkz. BEO. 2646-198429, 24 Temmuz 1321/6 Ağustos 1905; DH.TMIK.M. 200-32, 5 Temmuz 1319/18 Temmuz 1903; DH.TMIK. 244-25, 5 Temmuz 1319/18 Temmuz 1903.

${ }^{27}$ Bkz. BEO. 1733-129966, 23, 27 Eylül, 2, 27 Teşrîn-i evvel 1317/6, 10, 15 Ekim ve 9 Kasım 1901 tarihli belgeler; Y.PRK.ASK. 175-92, 24 Eylül 1317/7 Ekim 1901. Burada her ne kadar başlangıçta Zeynel'in Hınıs Kazası'nın Halekan Köyü'nden olduğu belirtilmişse de yapılan araştırmalar sonucu Kızılbaş ve Çarik (Çarekan) kabilelerinden olan bu köyde Zeynel adında birinin olmadığı belirtilmiştir ki, bu da kuvvetle muhtemel Zeynel'e ait bilgilerin karıştırılmış olmasından kaynaklanmıştır. Diğer yandan gaspedilen hayvanlar arasında da on baş at, otuz iki öküz, elli inek, yirmi düğe, yirmi tosun ve çeșitli sayıda diğer hayvanlardan olduğu belirtilmiştir.
}

Paşa aracılığı ile saraydan affını talep ettiği dile getirilmektedir (Fırat, 1961: 102; Kıran, 2019: 175). Buna, resmi belgelere de yansıdığı gibi aralarında Cibranlı ağalar da olmak üzere Zeynel ve Selim ağaların Cibranlı Mahmut Paşa'ya müracaatlarıyla talep ettikleri aflarını da ekleyebiliriz ki bu da başlangıçta Erzurum valisi tarafından uygun görülse de (DH.ŞFR. 264-30, 20 Temmuz 1317/2 Ağustos 1901) merkezi yönetim tarafindan kabul edilmeyecektir. Tabi burada önemli bir ayrıntı adı geçen Mahmut Paşa'nın da bu af talebinin ertelenmesi hususunda görüş beyan etmiş olmasıdır (BEO. 1940-145475, 12 Teşrîn-i evvel 1318/31 Ekim 1902). ${ }^{28}$

Hormek eşkıyaları hususunda Zeynel ile birlikte diğer bir takım aşiret mensuplarının da resmi söylemde olumsuzlandığı söylenebilir. Buna göre aşiret mensubu birçok kişi de gasp ve yağma eylemleri ile anılacaktır. Bunlar arasında Hüsnü Hasan'ın arkadaşı Resul ile silahlı adamları, ${ }^{29}$ Selim Ağa ve Zeynel Efendi'nin amcalarının çocuğu Hasan (yerelde Hesene Feqi olarak bilinir) isimleri dikkat çekicidir. Buna göre Hasan'ın da tıpkı Resul gibi civar köyleri basarak çok sayıda hayvanı gasp ettiği ve hatta bu köyler arasında vaktiyle Hamidiye Alayları'nda görev yapan ağaların mallarının olduğu da görülür. ${ }^{30}$ Adı geçen kişilerin yanı sıra isimleri yağma faaliyetleri ile anılan diğer bazı Hormekliler de söz konusudur. ${ }^{31}$ Ama bütün bu isimler yer yer anılmalarına rağmen, Zeynel devam eden bir istikrarla resmi söylemde zikredilip, yakalanmasına dair de sık sık telkin ve araştırmalarda bulunulur. $\mathrm{Bu}$ da her şeyden evvel Zeynel'in aşireti içerisinde olduğu kadar, rakip Cibranlılar ve devlet nezdinde endişe duyulacak bir sima olduğunun işaretidir. Çünkü Zeynel öncülüğündeki Hormekli eşkıyanın varlığı her şeyden evvel devletin bölgedeki otoritesi kadar, Cibranlıların Hormek aleyhtarı kolları için de bir tehlike ve bölgede otoritelerini kurma hususunda engel teşkil eder.

Zeynel öncülüğünde başından itibaren dile getirilen yasa karşıtı faaliyetler, kendisine isnad edilen gasp, yağma ve cinayet gibi hadiselerle resmi belgelere göre ilerleyen günlerde de devam eder. ${ }^{32}$ Belgelerin ifade ettiği doğruysa Zeynel ve arkadaşları faaliyetlerine 1911 yılına kadar etmiștir (DH.MKT. 1189-11, 21 Temmuz 1323/3 Ağustos 1907).

Sözlü tarihte dramatik ve aynı şekilde tutumları itibarıyla bir kahramanlık anlatısı olarak dile getirilen Zeynel'in eşi Fatma'nın (Fatık) ölümü de resmi belgelere yansır. Buna göre "Hormekli eşkıyanın" takibi ile görevlendirilen askerden bazı eşkıya aman dileyip, gasp ettiği eşyaları da geri verirken; Zeynel, kardeşi Veli, arkadaşları ve eşi

\footnotetext{
28 Tarihler esas alındığında bahse konu Mahmut Paşa'nın 1898 yılında öldürülen Cibranlıların Halilan kolundan Cibranlı Halit Bey'in babası olmadı̆̆

${ }^{29}$ Bir şikâyette Resul'ün Hınıs'ın Çeto Köyü'nü on iki silahlı adamı ile basıp köydeki "dokuz yüz kırk beş" koyunu așırdıkları bildirilmiștir. Bkz. DH.TMIK.M. 200-15, 29 May1s 1321/11 Haziran 1905.

30 Bir belgeye göre söz konusu kişi de eski Hamidiye Alayları mülazımlarından Ali Ağa'nın ağnam (vergi) ile topladığı dokuz yüz kırk koyunu gasp ederek Varto'ya götürecektir. Bkz. DH.TMIK.M. 201-30, 16 Haziran 1321/29 Haziran 1905.

${ }^{31}$ Süleyman, Feki Resul oğlu Hasan -ki bu önceki Hasan adlı kişi ile aynı olabilir- ve Gülabi oğlu Ağa gibi. Bkz. BEO. 2646-198429, 21, 24 Temmuz ve 6 Ağustos 1321/3, 6 ve 19 Ağustos 1905; BEO. 2808-210548, 1 Nisan 1322/14 Nisan 1906.

${ }^{32}$ Bkz. BEO. 2645-198304, 1, 3 Ağustos 1321/14, 16 Ağustos 1905; DH.MKT. 1189-11, 21 Temmuz 1323/3 Ağustos 1907.
} 
Fatma'nın arasında bulunduğu gruba dair polise gerçekleştirilen bir ihbar sonucu sığındıkları evde kuşatıldıkları, askere mukavemet göstermelerinden ötürü çıkan çatışmada beş askerin öldürülüp, dördünün yaralanırken, Zeynel'in eşinin öldürüldüğü ve geri kalanların da akşam karanlığından istifade ederek kaçtıkları dile getirilmiştir (DH.ŞFR. 366-109, 21 Haziran 1322/4 Temmuz 1906).

20. yüzyılın başı sadece Zeynel açısından değil, aşiretin reisi Selim Ağa açısından da devletin yakın takibinde olup, şekavetle suçlandığı yıllara tekabül eder. $\mathrm{Bu}$ durum Selim'in de firari olup, yakalanması için sürekli asker tarafindan arandığına işarettir. ${ }^{33} \mathrm{Bu}$ da aşiretin reisi olarak Selim'in de devletten beklediği karşılığı bulamadığını gösterir. Ki kendisi tam da bu yıllarda aşiret olarak Hamidiye Alayları'na kabulleri için birçok başvuru yapmıştı. Buradaki bir diğer önemli ayrıntı da Zeynel gibi Selim'in de artık aranan bir kaçak ve işlediği fiillerden ötürü henüz 1905 yılının başlarında gıyaben idama mahkûm edilmiş bir suçlu olduğudur ki (DH.TMIK.M. 200-32, 17 Nisan 1321, 14 Rebiyûlevvel 1323/30 Nisan ve 30 May1s 1905) aynı yıl içerisinde Cibranlıların Maksudan kolu tarafından öldürüldüğü görülecektir. $\mathrm{Bu}$ da Selim'in, yukarıda ortaya konulduğu gibi aşireti adına Hamidiye Alayları'na başvuru yaptığı tarihte devlet nazarında bir suçlu olarak görüldüğünü gösterir.

Gerek Zeynel gerekse Selim örneklerine bakıldığında, Hormekliler, bölgede yaşamsal varlıklarını sürdürme ve aleyhlerindeki Cibran kollarına karşı bir denge kurma hususunda Varto ve civarındaki diğer Kızılbaş aşiretlere nazaran daha önemli bir güç haline gelmiştir. Bu güç de sadece savunmadan ziyade yer yer saldırıya değin evrilen ve karşılığında Cibranlı muhalif güçlerin şikâyetlerine konu olacak denli önemli bir nicelik ve niteliksel boyut sergilemiştir.

\section{Sonuç}

Zeynel Efendi'nin, babasının öldürülmesi ile başlayan eşkıyalık hikâyesi, kişisel bir aile öyküsünün aşiret içinden başlayarak, aşiretler arası ilişkiler ve Hormek'in devlet idaresi ile münasebetlerini nasıl etkilediğine uzanır. Bu bakımdan, Zeynel'in birey olarak rolünün, söz konusu genel çerçeve içerisinde önemli bir noktaya tekabül etmekle beraber, mezkûr hadiseler akışını etkilediğini söyleyebiliriz. $\mathrm{Bu}$ hikâyede ilgi çekici olan husus ilk kırılmayı babasının ölümü, sonuncusunu da eşinin ölümüyle yaşamasıdır. Buna göre, ilkinde istemeyerek de olsa eşkıya olmasına sebebiyet veren ölüm hadisesi, onu zoraki olarak firari ve devletin nazarında şakî olarak yaşamaya zorlarken, bu süre zarfında aynı zamanda affını sağlamak için çeşitli arayışlara da sevk etmiştir. Fakat tüm bu arayışları yine de yaşamında önemli bir yer tutan eşinin ölümünü engelleyemediği gibi onun ölümünü beraberinde getirmiştir. Bunlara rağmen Zeynel yine de normal ve sıradan bir yaşantı için affedilmesine yönelik çabalarını durdurmamıştır. $\mathrm{Bu}$ da esas itibarı ile üzerine atılı "şak̂̂" rolü ile ne denli bütünleşipbütünleşmediği sorusunu ön plana getirir ki, yaşanan gelişmeler onun bunu hiç de gönüllü olarak gerçekleştirmediğini gösterir.

${ }^{33}$ Bkz. BEO. 2721-204003, 30 Teşrîn-i evvel, 29 Teşrîn-i sânî 1321/12 Kasım ve 12 Aralık 1905; BEO.2748-206090, 10 Kânûn-1 sânî 1321/23 Ocak 1906.
Zeynel, eşkıyalığın tüm dezavantajlarına rağmen evliliği ve çocuk sahibi olmayı sürdürdü. $\mathrm{Bu}$ da bilinegelen eşkıya anlatılarında pek de rastlanmayan bir durumdu. Görünen o ki eşinin ölümüne neden olan şey de tam olarak bu hususun getirdiği olumsuzluktan kaynaklandı. $\mathrm{Bu}$ da ona, Hobsbawm'ın "sosyal eşkıya" kategorisi içerisinde değerlendirebilecek bir özgünlük sağlamıştır. ${ }^{34} \mathrm{Bu}$ bakımdan söz konusu kategoriye uyan yanlarının yanı sıra evli ve çocuklu bir kişi olması da (Hobsbawm, 1995: 27, 121-122) Zeynel'i ayrıcalıklı kılmıştır. Böylece maruz kaldığı haksızlıktan ötürü eşkıya olması da onu diğer eşkıya tiplemelerinden ziyade "erdemli eşkıyalık" (noble robber) nitelendirmesine yaklaştıracaktır. ${ }^{35}$

Son olarak, Zeynel'in kişisel hikâyesi Hormek ve Cibran aşiretleri arasındaki uzun erimli ilişkilerden etkilendiği gibi bizzat bu ilişkiyi de etkilemiştir. İki aşiret arasındaki münasebetler, 19. yüzyıl ve bilhassa 1891 yılında Hamidiye Alayları'nın kuruluşuyla birlikte bölgedeki diğer aşiretler arası ilişkiler gibi yer yer çatışmalı bir hal aldı. Buna rağmen söz konusu ilişkiler yine de tek bir doğrultu ve bütüncül yaklaşıma sahip olmayıp, her iki aşiret içi dengelerin seyrine göre ilerlemiştir. $\mathrm{Bu}$ da her bir aşiretin kendi aşiret asabiyesinden evvel karşı aşiret içindeki gruplarla olan yakın ilişkilerine göre şekillenmişti.

Zeynel'i ortaya çıkaran ve farklı bir yaşantıya sevk eden koşullar tamamen bu atmosferin ürünüdür. Bununla beraber Cibran ve Hormek ilişkilerinin koşullara göre edindiği çoklu yapı üzerinde, Zeynel kadar, iki aşiret içerisinde beliren popüler simaların etkisi de oldu ki bunların başını da Hormekli Selim Ağa ve Cibranlı Halit Bey çekti. Bu açıdan Zeynel Efendi gibi her iki karaktere yönelik araştırmaların yapılmasının gerek bölge gerekse Hormek ve Cibran ilişkilerinin geçmişten beridir seyrede gelen muhtevasının anlaşılmasına yönelik önemli bir eksikliği dolduracağı aşikârdır. Burada bilhassa Halid Bey'in Birinci Dünya Savaşı ve sonrasında gün yüzüne çıkan "Kürtlük" bilincinden hareketle Kürt Teali Cemiyeti ve Azadi hareketindeki rolünden ötürü bölgedeki Kızılbaş aşiretler olarak Hormek ve Lolan ile temaslarını geliştirmeye çalışması (Fırat, 1961: 119-120; Fırat, 1968: 18) önemli bir noktaya tekabül eder. Buna rağmen söz konusu durumda da geçmiş, inanç ve çeşitli faktörlerin Kürtler içinde birleşme ya da ayrışma hususunda nasıl bir etkisinin olduğu göz ardı edilmemelidir. Bu yönüyle Arslan'ın da (2006: 104) ifade ettiği gibi bilhassa Milli Mücadele ve sonrasında Kızılbaş Hormek ve Lolanlıların yükselen bir güç olarak Mustafa Kemal ve hükümetine destek sunarken, Cibranlıların bunun karşısında bir pozisyon aldıkları söylenebilir.

\footnotetext{
34 "Sosyal eşkıya" tiplemesi hakkında bkz. Hobsbawm, 1995.

${ }^{35}$ Hobsbawm $(1995:$ 34, 39) erdemli eşkıya ile ilgili şu değerlendirmelerde bulunur: "1- Erdemli eşkıya suç işleyerek değil, adaletsizliğin kurbanı olarak kanun dıșına düșer. Ya da halk tarafından değil otoritelerce suç kabul edilen bazı eylemlerinden ötürü hüküm giyer. 2- Adaletsizliğe karşı çıkar. 3-Zenginlerden alıp fakirlere verir. 4- Nefsi müdafaa ve öcalma dışında adam öldürmez. 5- Şayet yaşarsa, kendi halkına, şerefli bir adam ve topluluğun saygı duyulan bir üyesi olarak geri döner. (Zaten kendi halkını hiçbir zaman terk etmez.) 6- Ona hayran olunur, yardım edilir ve desteklenir. 7- Topluluğun hiçbir üyesi ona karşı olan otoritelere yardımcı olmayacağından, ancak ihanete uğrayarak öldürülür. 8- Görünmez bir yaratık, ele geçmez, kurşun işlemez bir insan olarak kabul edilir.” Zeynel Efendi'nin yaşadıklarının da bütün bu özelliklerle uyuştuğu söylenebilir. Buna göre öldürülmese de, ihanet yani ihbar ile öldürülmeye teşebbüste bulunulduğu hem sözlü hem de resmi belgelerde açıktır.
} 


\section{Kaynakça}

Alanoğlu, M. (2020). 17. Yüzyıl Ortalarında Varto. History Studies, 12/3, 1143-1175.

Ali Kemali (1932). Erzincan: Tarihî, Coğrafî, İçtimâ̂, Etnoğrafì, İdarî, İhsầ Tetkikat Tecrübesi. İstanbul: Resimli Ay Matbaası.

Arslan, R. (2000). Şeyh Said Ayaklanmasinda Varto Aşiretleri ve Mehmet Şerif Fırat Olayı. İstanbul: Doz Yayıncilik.

Aytaş, G. (Ed.) (2010). Bingöl, Muş/Varto Yörelerinde Ocaklar, Oymaklar ve Boylarla Ilgili Araştırma Sonuçları. Ankara: Gazi Üniversitesi Türk Kültürü ve Hacı Bektaş Veli Araştırma Merkezi Yayınları.

Boğos Natanyan (2015). Ermenistan'ın Gözyaşı veya Palu, Harput, Çarsancak, Çapakçur ve Erzincan Hakkında Rapor. İçinde. Arsen Yarman Palu-Harput 1878, Çarsancak, Çemişgezek, Çapakçur, Erzincan, Hizan ve Civar Bölgeler. 2. cilt (Raporlar). 2. Baskı. (s. 75260). İstanbul: Belge Yayınları.

Bulut, F. (2013). Dersim Raporları. 5. Baskı. İstanbul: Evrensel Basım Yayın.

Çakmak, Y. (2019). Sultanın Kızılbaşları: II. Abdülhamid Dönemi Alevi Algısı ve Siyaseti. İstanbul: İletişim Yayınları.

Çalışlar, İ. [yayına hazırlayan]. (2010). Dersim Raporu. İstanbul: İletişim Yayınları, İstanbul, 2010.

Fırat, M. H. (1968). Yetmiş Beş Senelik Derbeder Bir Hayat Hikayesi. Ankara: Kardeş Matbaası.

Fırat, M. Ş. (1961). Doğu Illleri ve Varto Tarihi. 2. Baskı. Ankara: Milli Eğitim Basımevi.

Firat, K. (2000). Milletvekilliğine Değişmem. İstanbul: Doyuran Matbaası.

Gedik, E. (2019). Varto Alevileri: Etnisite, Din ve Kültür. İçinde: Ercan Çağlayan (Ed.), "Burası Muştur": Tarih, Toplum, Kültür ve Edebiyat. (s. 219-248). İstanbul: Pınar Yayınları.

Hobsbawm, E. (1995). Sosyal İsyancllar. Necati Doğru (Çev.). 2. Baskı. İstanbul: Sarmal Yayınevi.

Jandarma Umum Kumandanlığı (2010). Dersim. İçinde. Doğu Anadolu'da Toplumsal Mühendislik: DersimSason (1934-1946). İstanbul: Tarih Vakfi Yurt Yayınları.

Kıran, E. (2019). Serhat Kaplant. Ümit Fatma Furat (Çev.). İzmir: Na Yayınları.

Kocadağ, B. (1992). Doğuda Aşiretler, Kürtler, Aleviler. İstanbul: Ant Yayınları.

Ong, W. J. (2012). Sözlü ve Yazll Kültür: Sözün Teknolojileşmesi.Sema Postacıoğlu Banon (Çev.). İstanbul: Metis Yayınları.
Servet-i Fünûn, 1314: 244.

Tepeyran, E. H. (1998). Hatıralar. Faruk Ilıkan (yay. haz). 2. Baskı. İstanbul: Pera Tuzirzm ve Ticaret A. Ş.

\section{Arşiv Kaynakları}

Başbakanlık Osmanlı Arşivi (BOA).

BEO. 1733-129966

BEO. 1940-145475

BEO. 2645-198304

BEO.2646-198429

BEO. 2688-201552

BEO. 2721-204003

BEO.2748-206090

BEO. 2808-210548

DH.MKT. 1189-11

DH.MKT. 2495/41

DH.ŞFR. 260-16

DH.ŞFR, 264-30

DH.ŞFR. 332-78

DH.ŞFR, 366-109

DH.TMIK.M.146-20

DH.TMIK.M. 191-5

DH.TMIK. M. 200-15

DH.TMIK. M. 200-32

DH.TMIK.M. 201-30

DH.TMIK. M. 244/25

Y.EE. 139-15

Y.PRK.ASK. 175-92

Başbakanlık Cumhuriyet Arşivi (BCA).

30-1-0-0-42-249-7

\section{İstanbul Nadir Eserler Kütüphanesi}

Yerel Yer Numarasi: NEKYA90567/87

Link:http://nek.istanbul.edu.tr:4444/ekos/FOTOGRAF/905 67---0087.jpg (Erişim Tarihi: 20 Eylül 2020)

\section{Kişisel Görüşmeler}

Turabi Fırat, 1940 Varto doğumlu (20 Eylül 2020, Ankara).

Kamil Firat, 1975 Varto doğumlu (10 Temmuz 2020, Ankara). 